Gibson, Stephen ORCID:

https://orcid.org/0000-0002-5648-7669 (2009) The effortful citizen: discursive social psychology and welfare reform. Journal of Community \& Applied Social Psychology, 19 (6). pp. 393-410.

Downloaded from: http://ray.yorksj.ac.uk/id/eprint/445/

The version presented here may differ from the published version or version of record. If you intend to cite from the work you are advised to consult the publisher's version: http://dx.doi.org/10.1002/casp.1003

Research at York St John (RaY) is an institutional repository. It supports the principles of open access by making the research outputs of the University available in digital form. Copyright of the items stored in RaY reside with the authors and/or other copyright owners. Users may access full text items free of charge, and may download a copy for private study or non-commercial research. For further reuse terms, see licence terms governing individual outputs. Institutional Repository Policy Statement

\title{
RaY
}

Research at the University of York St John

For more information please contact RaY at ray@yorksj.ac.uk 
The Effortful Citizen: Discursive Social Psychology and Welfare Reform.

\author{
Stephen Gibson
}

York St John University

SHORT TITLE: DISCOURSE AND WELFARE REFORM

Acknowledgements: I would like to thank Jackie Abell, Susan Condor and an anonymous reviewer for their helpful comments on an earlier draft of this paper.

Word Count (inc. references and appendix): 9610

Address for correspondence: Dr Stephen Gibson, Faculty of Health \& Life Sciences, York St John University, Lord Mayor's Walk, York, YO31 7EX. Tel.: +44 (0) 1904 876581. Fax.: +44 (0) 1904 876500. E-mail: s.gibson@yorksj.ac.uk 


\begin{abstract}
The present study applies a broadly discursive approach to the representation of welfare reform and unemployment through an analysis of the deployment of an interpretative repertoire of effortfulness in posts to an internet discussion forum. It is argued that when posters construct versions of unemployed people or welfare recipients as characterised by 'laziness' or lack of 'effort' the attribution of responsibility for unemployment is frequently not the only piece of discursive business being attended to. In addition, posters attend to issues of their own accountability and, significantly, the accountability of the government or welfare system itself for the extent to which welfare recipients are formally held to account. It is argued that this approach extends previous social psychological work on the explanation of unemployment insofar as it pays attention to the context-specific functions performed by such explanations. Moreover, in orienting to the welfare system as having a responsibility to hold welfare recipients to account, posters are drawing on a set of discursive resources which essentially treat the government of individual psychology as a legitimate function of the welfare system.
\end{abstract}

Key Words: DISCOURSE; DISCURSIVE SOCIAL PSYCHOLOGY; EFFORT; EXPLANATIONS; INTERPRETATIVE REPERTOIRES; SOCIAL CITIZENSHIP; UNEMPLOYMENT; WELFARE REFORM 
The Effortful Citizen: Discursive Social Psychology and Welfare Reform.

A great deal has been written in recent years about the increasing conditionality which the UK Labour Government has placed on welfare benefits, and the assumptions regarding human subjectivity that are built into these changes. Rather less attention has been directed at the way in which the commonsense psychological assumptions underpinning these changes may be mobilised in everyday discourse on welfare issues. The need for such an analysis is particularly pressing given the assumptions about popular consciousness apparent in contemporary political discourse on welfare reform. The present paper utilises the analytic tools developed by discursive approaches to social psychology in order to begin to sketch some of the ways in which constructions of individual psychology can be used to perform particular rhetorical functions in relation to welfare, and in so doing to point to ways in which a broadly discursive approach might be able to add to existing social psychological and social policy analyses.

\section{Welfare Reform}

The UK welfare state has, since its inception, been held as the practical political manifestation of social citizenship - that component of citizenship which accords that individuals have certain social needs guaranteed by the state (cf. Marshall, 1950/1992). Although the welfare state has always been contributory in nature - and therefore social citizenship has always involved individuals meeting certain obligations in order that the welfare state should function (Rees, 1995) - since coming to power in 1997, the UK New Labour government have sought to accentuate the responsibilization of 
individuals, whereby welfare rights have been made increasingly contingent upon individuals meeting certain obligations (see e.g. Clarke, 2005; Dwyer, 2000, 2004; Lister, 2002; Lund, 1999). For example, in 2002 the entitlement to unemployment benefit - and indeed to a range of other benefits - was made contingent upon the individual attending regular meetings with an adviser at Job Centre Plus (Dwyer, 2004). Such measures reflect Giddens's (1998, p. 65) 'motto' for third way politics of ‘no rights without responsibilities' (italics in original) and Gordon Brown's call for a 'new politics founded on responsibilities as well as rights' (British Broadcasting Corporation, 2006). Indeed, the recurrent emphasis on responsibilization in political discourse points to the assumption of a deficit of discourses of responsibility in popular consciousness, and reinforces the message identified by Lister (2002, p. 127) that paid employment constitutes New Labour's 'supreme citizenship responsibility'.

Several commentators have suggested that New Labour's welfare reform agenda is characterised by a concern for individual morality (e.g. Fairclough, 2000; Heron \& Dwyer, 1999). For example, Heron and Dwyer (1999) quote Frank Field, the former Minister for Welfare Reform, expressing concern for the 'cancerous impact that much of welfare has on people's motivations' (p. 98). Heron and Dwyer rightly point to Field's concern for moral issues here, but for present purposes it is significant that Field refers specifically to the psychological term 'motivations.' Rose (1999, p. 265) has drawn attention to the links between psychology, morality and responsibilization in advanced liberal politics, arguing that '[p]overty and many other social ills are cast not in economic terms but as fundamentally subjective conditions. This is not a psychological subjectivity with social determinants, as in welfare regimes. It is an ethical subjectivity, and a cultural subjectivity. For community requires all to act by the 
ethics of virtuous self-responsibility, responsibility for oneself as a member of one's community.' However, although some authors have explored the way in which welfare policy has embodied certain assumptions about human nature and behaviour (e.g. Deacon \& Mann, 1999; Le Grand, 1997), there is as yet no exploration of the role of constructions of the psychological, and the use of specific psychological terms, in everyday discourse about welfare. In the present paper, I want to argue that social actors can use psychological terms in order to deal with issues of accountability on several levels in relation to welfare. It will be argued that such usages appear to be contingent upon mundane assumptions regarding individual responsibility for 'making an effort', and the straightforward nature of making such an effort. However, these versions of individual psychology are not constructed solely to hold individuals to account, but also function to hold government to account for failing to formally hold individuals to account. In order to do this, a position informed by discursive approaches to social psychology will be adopted. However, before outlining some relevant features of discursive social psychology, it is necessary to briefly review a tradition of social psychological research which has explored the everyday explanation of unemployment and attitudes to welfare.

\section{Attribution, unemployment and welfare}

In a series of studies in the 1980s, Furnham and his colleagues sought to understand beliefs about unemployment and welfare through the application of the insights of attribution theories and a broader concern with everyday explanations (e.g. Furnham, 1982a, b, 1983; Furnham \& Hesketh, 1989; Lewis, Snell \& Furnham, 1987; Payne \& Furnham, 1990). There is insufficient space here to review this work fully (see 
Furnham, 2001; Giron, 2001), or to do justice to its many merits. Instead, a brief review of some indicative findings is instructive as to the features of this work. Furnham (1982a) identified three broad classes of explanations for unemployment in Britain: Individualistic, societal and fatalistic (luck or chance). It was found that unemployed people in Britain tended to favour societal and fatalistic explanations for unemployment to a greater extent than employed people. Individualistic explanations were not rated particularly highly by either group, but were associated with political conservatism, a finding supported by Feather (1985) with an Australian sample. In further studies Furnham (1982b) found that people who scored highly on a measure of Protestant work ethic beliefs tended to favour individualistic explanations for unemployment, and Furnham (1983, p. 147) found that employed people tended to endorse negative attitudes towards unemployed people in receipt of social security benefits as being characterised by a 'lack of effort in trying to obtain jobs'. Finally, Furnham (1985) found that conservatism and Protestant work ethic beliefs were associated with negative attitudes towards social security claimants.

These studies are particularly pertinent to the present research given that most of them concentrate on the British context, and moreover provide a fascinating insight into people's willingness to endorse a range of explanations of unemployment and attitude items relating to welfare at a time of relatively high unemployment. In particular, the frequent presence of explanations involving psychological terms such as 'effort' and 'motivation' in these studies points to the importance of commonsense assumptions concerning psychology in explanations of unemployment and attitudes towards welfare and welfare recipients. However, research interest in this area declined during the 1990s, something which lead Giron (2001, p. 152) to ask 'is unemployment out of 
fashion for scientists?' Moreover, since this research was conducted, it is not only the social and economic landscape of the UK which has changed - social psychological approaches to attribution and explanation have also evolved (see e.g. Antaki, 1994; Langdridge \& Butt, 2004). Notwithstanding the merits of Furnham's work, it is vulnerable to the general re-specification of attribution outlined by Discursive Psychologists insofar as it neglects the fundamentally constructive and action-oriented nature of discourse (cf. Potter \& Wetherell, 1987). Specifically, it frequently involves the abstraction of explanations and attributions from the context of their occurrence and presents participants with pre-defined response alternatives. In doing so, the way in which attributions and explanations are bound up with issues of accountability are neglected (cf. Edwards \& Potter, 1992, 1993; and see below), and on the rare occasions when open-ended responses are collected (e.g. Lewis et al., 1987; see also Flanagan \& Tucker, 1999), there is a tendency to treat language as a straightforward reflection of underlying beliefs rather than as a means of constructing social reality and performing specific context-bound actions. Moreover, the concern to identify people's general beliefs about the causes of unemployment results in the neglect of the ways in which explanations of unemployment may be worked up as part of specific social practices. A perspective derived from discursive approaches to social psychology points to the importance of analysing particular instances without attempting to discern individuals' attributional style, or general tendencies to explain unemployment in a given way. The next section outlines some relevant features of this approach. 


\section{Discursive Social Psychology}

The approach adopted in the present paper draws on the insights of social psychological Discourse Analysis (DA; Potter \& Wetherell, 1987; Wetherell, 1998; Wetherell \& Potter, 1992) and the related Discursive Psychology (DP; Edwards, 1997; Edwards \& Potter, 1992; Potter, 2007a) and Rhetorical Psychology (Billig, 1991, 1996; Billig et al., 1988; and see Potter, 2007b, for an overview of discursive work in psychology). For the sake of simplicity, and to reflect the social psychological focus of the present analysis, I will refer to this approach as Discursive Social Psychology (DSP; see Potter, 1998). Without wishing to gloss over important distinctions between different shades of discursive work, it is useful to summarise some core principles of DSP. In short, DSP involves the re-framing of social psychological questions away from a concern with what may or may not be happening 'under the skull'. Instead, advocates of DSP typically argue for a focus on the ways in which social psychological topics and concerns are managed in discourse by social actors themselves (or 'members', to use the ethnomethodological term). Rather than seeing psychological concepts such as memory, attitudes, motivations, attribution and emotions as unobservable mental processes which can be inferred from linguistic behaviour, DSP sees such concepts as constructed in discourse in order to attend to some contextspecific discursive business.

Given this brief sketch of the principles of DSP, it is worth outlining in more detail some of the analytic concepts which are of particular use for the present analysis. As already suggested, the concern of some versions of DSP to explore the functions of psychological terms is of particular interest here, as is the pervasiveness of matters of accountability in discourse, and the analytic drawing of inferences regarding ideological 
or cultural themes, which are explored here through the identification of an interpretative repertoire. These features will be briefly outlined in turn.

Psychological terms are central to much discursive work insofar as it follows 'the ethnomethodological injunction to treat (what cognitivists take to be) mental objects as things whose 'reality' is their invocation in whatever human activities they appear in' (Condor \& Antaki, 1997, p. 338, italics in original). As an example, consider the following brief extract from Edwards's (1995, p. 332) data from a relationship counselling session, in which a man, Jimmy, draws attention to the length of his wife's skirt: 'Connie had a short skirt on I don't know'. Rather than treating the denial of knowledge (I don't know) as indicating a report of a mental state, Edwards shows how this formulation performs important interactional business in that it 'works to counter any notion of a watchful and suspicious jealousy' (p. 333).

Accountability is a pervasive feature of discourse (Edwards \& Potter, 1992). Social actors are frequently engaged in managing issues of responsibility - both their own and that of other people or institutions - in talk and writing. It is here that links to attribution theories are clearly evident - where the attribution of responsibility is at stake, issues of accountability are central (Antaki, 1994; Edwards \& Potter, 1992, 1993). Furthermore, discursive research has identified a variety of ways in which social actors orient to psychological issues, and use psychological terms, to attribute and disclaim responsibility in situations where accountability is at stake (e.g. Buttny, 1993). 
Ideological or cultural themes: The appropriateness of moving from a concern with how social actors themselves draw inferences (and make inferences available) in discourse to an analytic drawing of inferences concerning ideological or cultural themes has been the subject of extended debate in DSP and related approaches (e.g. Schegloff, 1997; Wetherell, 1998; Wooffitt, 2005; and the debates following Sims-Schouten, Riley \& Willig, 2007 and Speer, 2001). It is not my intention to rehearse these debates here, but it is nevertheless important to point out that the present analysis proceeds from the assumption that in dealing with specific instances of situated discourse and discursive psychological matters, we are also dealing with the themes of commonsense, something which Billig et al. (1988, p. 28) have termed 'lived ideology'. Moreover, psychological terms themselves may constitute discursive resources within particular 'lived ideologies.' The approach adopted here, then, shares Wetherell's (2003, p. 13) aim of identifying the 'cultural resources' used in discourse. As will become apparent, these 'cultural resources' may include assumptions about the psychological, and the use of psychological terms themselves. There are several techniques for the identification of such cultural resources in DP, three particularly influential analytic concepts being interpretative repertoires, ideological dilemmas and subject positions (see Edley, 2001, for a comparison). The present analysis will draw primarily on the concept of interpretative repertoires.

Interpretative repertoires were defined by Potter \& Wetherell (1987, p.149) as 'recurrently used systems of terms used for characterizing and evaluating actions, events and other phenomena', and are one of the central analytic concepts of social psychological DA (see also Potter, Wetherell, Gill \& Edwards, 1990; Wetherell \& 
Potter, 1988; cf. Gilbert \& Mulkay, 1984). Although, as Potter (2007c) has recently pointed out, a focus on interpretative repertoires is less a feature of current work in DP, they remain central to much discursive work addressing social psychological issues (e.g. Croghan \& Miell, 1999; Lawes, 1999; Reynolds \& Wetherell, 2003; Reynolds, Wetherell \& Taylor, 2007; Riley, 2002).

The present analysis applies the insights of DSP in order to explore the ways in which an interpretative repertoire of effortfulness is used in addressing issues of accountability in relation to un/employment. The aim is not to suggest that all social actors in all contexts are somehow constrained by an individualistic discourse of 'effort' in relation to social citizenship - alternative explanations of unemployment in terms of social forces (e.g. Dean, 2004; Edelman, 1977) or fatalism (e.g. Furnham, 1982a) are clearly possible. Indeed, Gibson (2007) has shown how, in adolescents' research interview talk the effortfulness repertoire was associated with in-principle questioning concerning un/employment rights and responsibilities, whereas in another context interviewees drew upon an alternative repertoire of immigration as a cause of unemployment. However, the aim of the present paper is not to provide a comprehensive analysis of welfare discourse, but to sketch the discursive features of invocations of the 'effortfulness' repertoire in one specific discursive context - an internet forum in which individuals post comments on issues in the news - related to what might broadly be 
termed welfare reform ${ }^{1}$ or social citizenship. In particular, the analysis draws attention to the way in which 'effortfulness' is used not only to attribute individual responsibility for unemployment, but also to manage the accountability of the posters themselves and to hold the welfare system or government to account for the extent to which people who do not display 'effort' are formally held to account. In so doing, it is hoped to illustrate the utility of a qualitative analysis informed by DSP for studies of welfare and social citizenship, and to highlight the importance of rekindling social psychological interest in ordinary accounts of unemployment.

\section{Data \& Analytic Procedure}

\section{Data}

The materials that form the dataset for the present analysis come from a debate on the BBC news website. The debate coincided with the release of the Freud (2007) report on the future of the UK welfare system and is part of an ongoing feature entitled 'Have Your Say' in which readers of the website are invited to post comments addressing significant issues in the news. ${ }^{2}$ The debate used for the present analysis was headed with the question 'Is the welfare system working?' and began on $4^{\text {th }}$ March 2007

\footnotetext{
${ }^{1}$ At this point, it is worth noting Fairclough's (2000) observation that the term 'reform' itself performs an important ideological function insofar as it is suggestive of a progressive, forward-thinking process of change.

${ }^{2}$ See

http://newsforums.bbc.co.uk/nol/thread.jspa?threadID=5675\&\&\&\&edition=1\&ttl=2007 0730162708. Retrieved $25^{\text {th }}$ September, 2007. Quotations reproduced by permission of the BBC.
} 
at 9.48 GMT. A copy of the full introduction to the debate is reproduced in Appendix 1. According to the information available on the website, a total of 3319 comments were posted, with 2698 comments being published on the website. More information regarding the running of the debate can be found on the website itself. For the purposes of the current analysis, a subset of 183 comments were selected on the basis of what are known as 'reader recommendations'. This function of the website allows readers to recommend a comment contributed by someone else. The website displays the number of recommendations for each comment, and in order to provide a manageable dataset a cut-off point of a minimum of 10 recommendations was used for the present analysis.

Selecting the data in this way may ordinarily raise issues regarding the removal of posts from the sequential turn-taking context in which they were posted. Specifically, recent research points to the importance of recipient design and turn-taking in online contexts (e.g. Antaki, Ardévol, Núñez \& Vayreda, 2006). However, the 'Have Your Say' forum does not allow posters to reply to previous posts directly. Instead all posters simply post a comment which appears in the general 'thread' of comments. This is not to suggest that recipient design is not a feature of the comments - as will become clear below, many posts are constructed in such a way as to manage the way in which they might be received. However, the design of the forum makes an explicit focus on sequential turn-taking itself inappropriate for the present study.

A brief note on ethical issues is also appropriate at this point. In the recent British Psychological Society (BPS) guidelines on the use of the internet for research purposes, researchers are cautioned that 'it is strongly arguable that postings to both synchronous or asynchronous discussion groups ... do not automatically count as public activity' (BPS, 2007, p. 3). However, in the present case, it is notable that the 'Have 
Your Say' forum is freely available and is not password protected. Nor is the forum hosted by a specific special interest website where posters might reasonably expect to be reaching a small, well-defined audience (see e.g. Brownlow \& O’Dell, 2002). In contrast, the nature of the $\mathrm{BBC}$ - the organization hosting the forum - makes it perhaps one of the most self-evidently public forums one might engage in on the internet. Certainly, the posts are being analysed by an academic researcher - something that the posters no doubt did not intend to happen to their comments - but in this respect the comments can be seen as analogous to 'letters to the editor' published in traditional print media, which have frequently been used in qualitative research (e.g. Lynn \& Lea, 2003; Richardson, 2001). Nevertheless, in the interest of maintaining anonymity as far as possible, the comments reproduced in the present paper are presented minus identifying information such as the name and location of the poster.

\section{Analytic Procedure}

After initial reading of the data suggested that many posters of comments drew on themes of effort, laziness and hard work, the analytic corpus of 183 comments was coded for uses of terms referring to individual effort - the effortfulness repertoire. This yielded data from 55 comments. The effortfulness repertoire included any terms or figures of speech which referred to lack of effort or laziness, such as lazy/laziness, work-shy, idle/idleness, feckless, layabouts, work ethic, as well as effort itself, and references to hard work, people who can't be bothered and a cluster of figurative terms which evoke an image of people sitting or lying down, such as references to people sat around or, more colloquially, lying around on their backsides. References to spongers, scroungers and parasites were also included on the basis that these terms were used to 
construct people as willing to receive an income without working for it. Each individual comment was analysed as a whole - although only one line in a comment might draw upon the effortfulness repertoire it was considered in the context of the functions it performed in relation to the comment as a whole. The decision to characterise this repertoire as one of effortfulness (rather than, for example, laziness) was made as effort can be used in both a positive or negative sense (i.e. one can 'make an effort' or 'lack effort'). This reflects the way in which the repertoire itself was used not only to construct groups of people as lazy or work shy, but also to contrast these groups with hard working people - both are examples of the repertoire, not simply those which refer to an absence of effort, and both are therefore of interest in the present analysis.

Analysis proceeded in accordance with the principles of DSP (as outlined above), together with supplementary techniques such as the method of constant comparison (cf. Glaser \& Strauss, 1967) and deviant case analysis (see e.g. Seale, 1999).

\section{Analysis}

In the social psychological literature on ordinary explanations of unemployment, a lack of effort tends to be offered as the exemplar par excellence of an individualistic explanation for unemployment. Similarly, in the present dataset individuals were frequently held to account for 'laziness' or for being 'work-shy'. For example: ${ }^{3}$

\footnotetext{
${ }^{3}$ In all the comments presented here, punctuation and spelling is reproduced as in the original. All comments are reproduced in full, except for information regarding date and time of posting, name and location of poster, and number of recommendations.
} 


\section{Comment 1: 'bone idle bull'}

Being a parent is not a job, its a choice..... and yes, I am the parent of 3 kids (now 12,14,18), and both my wife and I have worked (without claiming benefits) since they began all school.

Ive never heard so much bone idle bull as all the listed excuses to be jobless and sponging off the state.

Stop watching mind numbing daytime TV at my expense and get a job.

It should be apparent from this comment that, in line with the general DP approach to issues of attribution and accountability (Edwards \& Potter, 1992; 1993), it is not only other people's responsibility for unemployment which is at stake here. Equally, the poster attends to issues of his own accountability by claiming category entitlement to comment on how to avoid unemployment by constructing his (and his wife's) status as working parents. However, in attending to issues of his own accountability he is also setting out grounds for holding others to account. He works up a contrast between himself and his wife as working parents and a category of people who are 'sponging off the state'. The latter's accounts for unemployment are dismissed as 'bone idle bull ... excuses', before glossing the defining activity of this category of people as 'watching mind numbing daytime TV', and instructing them to 'get a job'. This category of people are constructed in such a way as to be both responsible for their own unemployment and unwilling to seek employment. Furthermore, employment itself is constructed as relatively unproblematic and easy to obtain - the implication being that 
provided one stops watching 'mind numbing daytime TV', finding a job should be fairly straightforward.

However, comments which were limited simply to holding individuals to account were relatively rare $(\mathrm{N}=7)$. The 'effortfulness' repertoire was also used for commenting on, or suggesting improvements to, the welfare system. Such comments frequently took the form of explicit statements regarding the welfare system $(\mathrm{N}=24)$. For example:

\section{Comment 2: 'all these lazy people!'}

I think Britain's welfare state is a complete joke. Hardworking, honest, tax paying people like myself continually subsidising all these lazy people! I am sick of it!

I have been working full time, non stop since finishing my education in 1981, if I can do it, so can everybody else!! (and, I never got pregnant!) My only exception is the genuinely "disabled"

In this comment, the poster mobilises a similar contrast to the poster in comment $1 . \mathrm{A}$ distinction is drawn between '[ $\mathrm{h}]$ ardworking, honest, tax paying people like myself' and 'all these lazy people'. Attending to issues of her own accountability raised by her positioning of herself in the 'hardworking' category, she then provides a description of her own working history. This is worked up through the use of an Extreme Case Formulation (ECF; Pomerantz, 1986) (non stop) and the provision of detail (in 1981), and provides a basis for her subsequent claim that 'if I can do it, so can everybody else!' Here we have society constructed as consisting of two groups of people defined by their 
enduring characteristics - the hardworking (who are also honest taxpayers), and the lazy. Nevertheless, the route from the latter group to the former is treated as straightforward, with no reason why 'everybody' cannot do as the poster has. The speaker makes an exception of people who are 'genuinely "disabled", thereby orienting to the possibility that some people's claims to disability may not be 'genuine', which draws implicitly on a genuine-bogus distinction familiar from research on the representation of asylum seekers (e.g. Lynn \& Lea, 2003). As in comment 1, working hard or making an effort is treated as a mundane activity which (almost) anyone should be able to do. However, in addition to attending to matters of her own accountability and holding individuals to account for being 'lazy', a third level of accountability is attended to here. The poster's opening sentence (I think Britain's welfare state is a complete joke) marks her comment as a criticism of the welfare system itself. It is hardly surprising that such criticisms appear in a debate in which contributors were explicitly asked to comment on the welfare system, yet what is significant is the way in which the construction of individuals as responsible for their own status as either lazy or hardworking is used to hold the system itself to account. In effect, then, the system is a 'joke' because it fails to hold individuals to account when they do not meet their responsibilities.

Posters also sometimes drew on the effortfulness repertoire in suggesting alternatives to the present system $(\mathrm{N}=11)$. For example:

\section{Comment 3: 'proof of their efforts'}

Having lived in Canada for many years, those on job seekers allowance must show proof of their efforts to find work. They have to provide names of 
employers that they have visited in their effort to seek employment. Those who cannot show proof are denied benefits. They must seek work at companies commensurate with their skills. We must do more to force absent fathers to pay for their offspring rather than merely expect taxpayers to fund them.

The poster claims entitlement by stating that s/he has 'lived in Canada for many years', before going on to construct the Canadian system in terms of the requirement for people to demonstrate their 'efforts' to seek suitable employment as a condition for the receipt of welfare benefits. Unlike comments 1 and 2, the poster does not provide a gloss on the character of welfare recipients, yet welfare is nevertheless contingent upon individual 'effort'. However, we can again see how the welfare system is accorded the role of monitoring individual 'effort' (by, for example, collecting 'proof of their efforts'). To the extent that the welfare system does not do this, by implication, it can be held to account.

Finally, the effortfulness repertoire was also used to hold the government at least partially accountable for failing to sufficiently hold 'lazy' individuals to account $(\mathrm{N}=$ 9). For example:

\section{Comment 4: 'lying around on their backsides'}

The sad thing is that we all know the money will be taken off the geniune cases while the wasters of this country continue to bleed it dry while lying around on their backsides. We must all like what is happening. A government is meant to be representative of its people, never has this been further from the truth. It's 
important for you all to do what you can to survive, do not lie but volunteer nothing. It's them and us.

\section{Comment 5: 'idle morons'}

My girlfriend works at a sixth form college and time after time after time she hears comments from female students, such as, 'If I get pregnant, I'll get a house.'

Here's an idea: Use contraception and try working for a living!!

It's far too easy for idle morons to be dished out benefits and housing, while genuine, hardworking individuals save hard for what they have. The government needs to toughen up! Good on you, Mr Blair!

In comment 4, the poster draws a distinction between 'genuine cases' and 'wasters', the latter being characterised as 'lying around on their backsides' and as continuing to 'bleed it [the country] dry'. The temporal reference to continuity, coupled with the earlier suggestion that 'we all know' what the outcome of any attempt to change the welfare system will be, constructs the situation as enduring and inevitable, something which the government is held accountable for due to its failure to be 'representative of its people'. By contrast, in comment 5, the government, and specifically the then Prime Minister Tony Blair, is applauded for their plans to change the welfare system. However, the 'effortfulness' repertoire is used to do similar discursive work: The welfare system as it currently stands is criticised for dishing out 'benefits and housing' to 'idle morons', a category of people who are contrasted with 'genuine, hardworking individuals'. Note again the way in which the poster attends to issues of personal 
accountability by prefacing his invocation of 'idle morons' with a description of his girlfriend's experiences. This description makes use of a number of devices for the construction of factuality (Potter, 1996), such as the use of repetition (time after time after time) which exhibits a three part structure (Jefferson, 1990), reported speech (see e.g. Holt, 1996), and the construction of a reliable identity for the source of these reported remarks (Pomerantz, 1984). The source is described as holding a relevant position (works in a sixth form college) and as being in a relationship of trust with the poster (My girlfriend). These devices serve to provide a basis for his subsequent claims - they are based on the experiences of a trusted other, rather than, for example, any prejudicial sentiment on the part of the poster. In addition, the use of these devices suggests that characterising people as 'idle morons' is not in itself a straightforward activity - as in many discursive arenas social actors may need to attend to the possibility that such remarks may not elicit agreement from recipients, but lead to inferences about the character of the speaker, or in this case poster. Unlike in comment 4 , the poster applauds the government's plans, but the effortfulness repertoire is again used to hold individuals to account, and, more specifically, to position them as accountable to government. By implication then, the government itself can be held to account if it is not seen to be holding 'idle morons' to account.

Comments 1-5 have in common the assumption that the right to receive welfare benefits should be denied to those who are 'lazy' or who do not display 'effort'. However, lest it be suggested that this analysis reveals some kind of pervasive discursive false consciousness from which ordinary social actors are unable to break free, there were eleven comments in which posters themselves explicitly took issue with the construction of welfare recipients as 'lazy' or 'work shy', or as not 'genuinely trying 
to find work'. These are worthy of close attention insofar as they provide opportunities to identify cases which may help to identify the limits of the analytic points presented thus far. Analysis of these cases suggests that many of these in fact exemplify the general observations outlined above. For example:

\section{Comment 6: "lazy" or "work shy",}

The amount of contempt I see here for those who are genuinely unable to work is sickening. We're not a civilised country at all, we stopped being a civilised society when Mrs Thatcher created such a selfish and egotistical society. Just look at the ignorant comments here! Everybody is presuming that all benefit claimants are either "lazy" or "work shy".

Will my comment be posted? Probably not, as not to offend the "it's all about me" type.

This forum is insulting to the chronically ill.

As mentioned above, the nature of the 'Have Your Say' forum precludes posters from responding directly to previous comments as part of a 'thread', however, this comment is instructive about the way in which the sorts of formulations represented by comments 1-5 were received by some other posters. The poster links the use of the terms 'lazy' and 'work shy' to the existence of a 'selfish and egotistical society', responsibility for which is attributed to former Prime Minister Margaret Thatcher. The use of quotation marks helps the poster to indicate that the terms 'lazy' and 'work shy' are being mentioned rather than used (see Garver, 1965, on the origins of this distinction; and see Potter \& Litton, 1985, for its relevance to social psychology and discourse). Note also 
the use of ECFs in the sentence 'Everybody is presuming that all benefit claimants are either "lazy" or "work shy".' The presumption is attributed to every poster participating in the debate, and is said to apply to all claimants - this presents the poster's view as a corrective which goes against the prevailing consensus. The poster's rhetorical strategy involves the construction of a group of people who are 'genuinely unable to work' (later glossed as the 'chronically ill') in order to challenge those posters (every other poster) who dismiss all benefit claimants as 'lazy' or 'work shy'. However, the underlying assumptions here are not too different from those apparent in the other comments. As in comments 2 and 4, many posters constructed categories of 'disabled' or 'genuine' claimants who were exempted from charges of 'laziness', and thereby treated as legitimate welfare recipients. This is precisely what the poster in comment 6 is doing, albeit with a difference in emphasis: Not all claimants are 'lazy' or 'work shy', some are 'genuinely unable to work' and/or 'chronically ill' and are thereby entitled to receive benefits. The implicit assumption remains: Anyone who is not 'genuinely unable to work' may well be 'lazy' and therefore not entitled to welfare.

Another type of case which ultimately provides support for the analysis involves comments in which posters challenge the assumption that welfare recipients are 'lazy' by referring explicitly to their own circumstances. For example:

\section{Comment 7: 'Does that make me a layabout'}

I work harder now that I'm on benefits than I ever did when I was in full time employment.

The reason?

I'm a full time carer for my disabled wife. 
I would dearly love to go back to work, but if I did, my wife would suffer.

Does that make me a layabout, a sponger, or a benefit cheat?

You decide.

In this comment the poster's construction of himself as 'work[ing] harder' now that he is receiving welfare benefits than when he was in paid employment is used to challenge the construction of welfare recipients in terms of laziness (through the use of the colloquial term 'layabout'). However, the assumption that one's income should be dependent upon effortful labour of some kind is again apparent in the very terms in which he constructs himself (I work harder...). This poster is again criticising a tendency to treat all benefit claimants as 'layabouts', not the assumption that one's right to an income is ordinarily dependent upon one's engagement in effortful labour. Furthermore, the poster orients to a norm of engaging in paid employment (I would dearly love to go back to work), and the responsibility of individuals to do so.

However, by positioning himself as a caring husband he is able to argue his exemption from this responsibility by invoking a greater responsibility to his wife (if I did, my wife would suffer).

It is worth considering one final case in which the effortfulness repertoire is used without any apparent attribution of responsibility to individuals:

\section{Comment 8: 'get off their backsides for $£ 200$ per week' ${ }^{4}$}

You can't expect people to get off their backsides for $£ 200$ per week (before tax and n.i.). I wouldn't, why should I expect somebody else to? People would be

\footnotetext{
${ }^{4}$ The reference to 'n.i' in this comment refers to National Insurance contributions.
} 
bringing home around $£ 165$ per week and are supposed to pay their rent, council tax, food, utility bills, travel to work etc. Impossible. Tax credits are nonsense. Just pay people enough money to live on.

This comment stands out from the others insofar as the poster orients to a responsibility on the part of employers and the state to ensure that paid work provides individuals with a living wage, rather than the responsibility of individuals to engage in paid work. Underscoring this is a treatment of an individual's decision to engage in paid employment as the outcome of a rational calculation, rather than as a moral obligation. In this sense, then, this comment constitutes a 'deviant case': The effortfulness repertoire is not being used to deal with moral issues concerning the deservingness of welfare recipients. However, although the use to which the effortfulness repertoire is put differs, the commonsense psychological assumptions underlying its use have more in common with previous posts than may at first be apparent. As with other posts, people 'get[ting] off their backsides' is treated as a relatively straightforward and unproblematic activity which is under the control of autonomous individuals. Indeed, the construction of a rational actor making a considered choice concerning whether or not to engage in paid employment actually echoes other comments in which welfare recipients were constructed as having made a choice, and held accountable for it (e.g. in comment 5 above, where the poster reports overheard conversations). In this comment the poster positions such a decision as rational, understandable and therefore defensible, whereas other posters position such a decision as immoral and therefore indefensible. The key difference is that here the poster prioritises a rational rather than a moral frame, and in so doing is able to shift accountability to employers and the state. Furthermore, 
the poster still attends to a norm of engagement in effortful labour, the implication being that once a living wage is in place, people can be expected to 'get off their backsides'.

To summarise, then, 'making an effort' is treated as a simple, straightforward activity which is, above all, something over which the individual has control. However, it is not the case that the repertoire is only ever used to hold individuals to account. Instead, the welfare system or the government itself can be held accountable insofar as it fails to hold these individuals to account. Thus not only can a lack of 'effort' be treated as accountable, but a failure to treat a lack of 'effort' as accountable can itself be accountable. Equally, as comment 8 shows, employers and the state can be held to account for failing to pay wages of a sufficient level such that individuals might be expected to (and therefore held accountable for any failure to) 'get off their backsides'. The effortfulness repertoire is therefore used to manage accountability on three levels. First, it can be used by individual posters to present themselves as 'hard working' Second, it can be used to construct people as accountable for the extent to which they are 'lazy' or 'make an effort'. Third, it can be used to hold institutional or systemic actors (the welfare system, government or employers) to account.

\section{Discussion}

The discursive critique of attribution theory (Antaki, 1994; Edwards \& Potter, 1992, 1993) has drawn attention to the problems inherent in studying attributions and, more broadly, explanations, in isolation from the discursive contexts in which they occur. By moving from an approach which asks people to identify in-principle causes of, or explanations for, unemployment, to an approach which explores the way in which 
one particular type of explanation for unemployment is constructed within the context of arguments about welfare reform, the present analysis sacrifices the goal of developing general statements regarding how people understand unemployment to consider instead the context-specific uses to which explanations of unemployment can be put. Moreover, such an approach allows us to see how in these specific discursive settings, more than simply responsibility for unemployment in general might be at stake. Rather, people may attend to issues of their own accountability (Edwards \& Potter, 1992) - both for what they say/write and for their own employment status - as well as constructing particular explanations of unemployment in order to argue for particular courses of action on the part of institutional or systemic actors.

There are clearly other ways of talking about welfare and related issues - it is not the case that the effortfulness repertoire represents the way in which welfare and unemployment is discursively represented. To suggest this based on the data presented here would be remiss. However, the aim of the present study was not to provide a comprehensive analysis of all the possible ways of talking about welfare, but to analyse in detail the uses to which one interpretative repertoire was put in one quite specific discursive context relating to welfare. Needless to say, further research will be required to extend this analysis in order to show how this - and other - repertoires operate in different contexts. What the uses of the effortfulness repertoire identified here do show, however, is that arguments over welfare may be tied up with assumptions concerning commonsense psychology. Whether one should be entitled to receive benefits can be treated as being contingent on 'effort', and judgments concerning one's entitlement to support are inseparable from judgements concerning whether one possesses undesirable character traits such as 'laziness', with the assumption being that stopping oneself from 
being 'lazy' is both the responsibility of the individual and relatively straightforward. In this sense, then, the repertoire is frequently used to locate responsibility in the individual and in so doing inevitably justifies inequalities and unemployment as the outcome of a fair and natural process - something akin to saying that you get out what you put in.

Moreover, the present analysis points to the way in which the effortfulness repertoire can perform a variety of functions in discursive practice. In addition to the use of effortfulness to locate the cause of unemployment at the level of the individual, the repertoire was also central to the management of the accountability of the individual poster, and to holding the government or welfare system to account for failing to hold individual 'lazy' people to account.

This final use of the effortfulness repertoire - the construction of 'lazy' unemployed people as a means of holding systemic or institutional actors to account points to a sense in which the welfare system can be treated by social actors themselves as a means of governing welfare recipients. The significance of the posters' use of the effortfulness repertoire lies not only in the assumption of individual responsibility for 'making an effort', but also in the way in which the welfare system and/or the government is treated as having a responsibility to police welfare claimants and, moreover, to make judgements concerning their levels of effort. In this sense, then, we might say that posters are orienting to the welfare state as a means of governing individual psychology. Income is dependent upon effort, and the welfare system makes judgments concerning effort in order to determine the legitimacy of welfare claimants. In order for an illegitimate claimant to become legitimate, appropriate levels of effort must be displayed and, moreover, individuals themselves are responsible for their levels 
of effort. Such assumptions have been identified as forming the basis of recent changes in welfare regimes (e.g. Rose, 1999), however the present analysis shows how the mobilisation of a particular discursive repertoire - effortfulness - suggests that such assumptions can be drawn upon in the discourse of social actors themselves. This is significant insofar as recent pronouncements from the UK Labour Government point to an assumption that public discourse tends to neglect responsibilities in favour of rights, with associated policy initiatives seeking to redress this perceived imbalance. If, however, ordinary social actors have ready access to cultural resources such as the effortfulness repertoire, it would seem that norms of individual responsibility are firmly culturally entrenched, with those who are perceived to be transgressing these norms potentially subject to opprobrium and castigation. Indeed, it might be suggested that official discourse and policy initiatives need to be redressed in the opposite direction, with assumptions of individual autonomy and personal responsibility being balanced by alternative discourses.

Rose (1999, p. 267) has suggested that in advanced liberalism 'citizenship becomes conditional upon conduct' and that, furthermore, for those excluded from citizenship 'control is now to operate through the rational reconstruction of the will' ( $p$. 270). This essentially involves techniques aimed at rectifying the psychological deficiencies of those whose conduct fails to reach appropriate standards of autonomy and self-responsibility. Rose's argument concerns the broad sweep of policies and practices which make up advanced liberalism, yet the present analysis suggests that, on a much more everyday level, social actors themselves can bring to bear similar assumptions regarding autonomy, responsibility and psychology. Indeed, one might suggest that the processes identified by Rose exist in a dialectical relationship with the 
more mundane cultural resources drawn upon by ordinary social actors. The way in which posters to the 'Have Your Say' forum drew on the effortfulness repertoire suggests that not only do people have routine access to these cultural resources, but that they can use them to call for the very form of governance that Rose identifies - the exhortation that the state identify those with 'pathologies of the will' (p. 269) and deal with them accordingly. Indeed, the observation that political discourse may involve the assumption that members of the populous need to be reminded about their responsibilities is rather striking in light of the seemingly mundane way in which social actors themselves orient to such responsibilities. In effect, government is echoing popular discourse in calling for a rebalancing of rights and responsibilities, while constructing a version of popular sentiment as lacking a discourse of responsibility. 


\section{References}

Antaki, C. (1994). Explaining and arguing: The social organization of accounts. London: Sage.

Antaki, C., Ardévol, E., Núñez, F. \& Vayreda, A. (2006). "For she who knows who she is:" Managing accountability in online forum messages. Journal of Computer-Mediated Communication, 11, 114-132. DOI: 10.1111/j.10836101.2006.tb00306.x

Billig, M. (1991). Ideology and opinions: Studies in rhetorical psychology. London: Sage.

Billig, M. (1996). Arguing and thinking: A rhetorical approach to social psychology ( $2^{\text {nd }}$ ed.). Cambridge: Cambridge University Press.

Billig, M., Condor, S., Edwards, D., Gane, M., Middleton, D. \& Radley, A. (1988). Ideological dilemmas: A social psychology of everyday thinking. London: Sage.

British Broadcasting Corporation (2006). In full: Gordon Brown's speech. Retrieved $18^{\text {th }}$ November, 2007, from http://news.bbc.co.uk/1/hi/uk_politics/ 5378312.stm

British Psychological Society. (2007). Report of the working party on conducting research on the internet: Guidelines for ethical practice in psychological research online. Leicester: BPS.

Brownlow, C. \& O’Dell, L. (2002). Ethical issues for qualitative research in on-line communities. Disability and Society, 17, 685-694. DOI: $10.1080 / 0968759022000010452$

Buttny, R. (1993). Social accountability and communication. London: Sage. 
Clarke, J. (2005). New Labour's citizens: Activated, empowered, responsibilized, abandoned? Critical Social Policy, 25, 447-463. DOI: $10.1177 / 0261018305057024$

Condor, S. \& Antaki, C. (1997). Social cognition and discourse. In T. A. van Dijk (ed.), Discourse as structure and process. London: Sage.

Croghan, R. \& Miell, D. (1999). Born to abuse? Negotiating identity within an interpretative repertoire of impairment. British Journal of Social Psychology, 38, 315-335. DOI: 10.1348/014466699164194

Deacon, A. \& Mann, K. (1999). Agency, modernity and social policy. Journal of Social Policy, 28, 413-435.

Dean, H. (2004). Popular discourse and the ethical deficiency of 'third way' conceptions of citizenship. Citizenship Studies, 8, 65-82. DOI: $10.1080 / 1362102042000178391$

Dwyer, P. (2000). Welfare rights and responsibilities: Contesting social citizenship. Bristol: Policy Press.

Dwyer, P. (2004). Creeping conditionality in the UK: From welfare rights to conditional entitlements? Canadian Journal of Sociology, 29, 265-287.

Edelman, M. (1977). Political language: Words that succeed and policies that fail. New York: Academic Books.

Edley, N. (2001). Analysing masculinity: Interpretative repertoires, ideological dilemmas and subject positions. In M. Wetherell, S. Taylor \& S. J. Yates (eds), Discourse as data: A guide for analysis. London: Sage. 
Edwards, D. (1995). Two to tango: Script formulations, dispositions, and rhetorical symmetry in relationship troubles talk. Research on Language and Social Interaction, 28, 319-350. DOI: 10.1207/s15327973rlsi2804_1

Edwards, D. (1997). Discourse and cognition. London: Sage.

Edwards, D. \& Potter, J. (1992). Discursive psychology. London: Sage.

Edwards, D. \& Potter, J. (1993). Language and causation: A discursive action model of description and attribution. Psychological Review, 100, 23-41. DOI: 10.1037/0033-295X.100.1.23

Fairclough, N. (2000). Discourse, social theory, and social research: The discourse of welfare reform. Journal of Sociolinguistics, 4, 163-195. DOI: 10.1111/14679481.00110

Feather, N. T. (1985). Attitudes, values, and attributions: Explanations of unemployment. Journal of Personality and Social Psychology, 48, 876-889. DOI: $10.1037 / 0022-3514.48 .4 .876$

Flanagan, C. A. \& Tucker, C. J. (1999). Adolescents' explanations for political issues: Concordance with their views of self and society. Developmental Psychology, 35, 1198-1209. DOI: 10.1037/0012-1649.35.5.1198

Freud, D. (2007). Reducing dependency, increasing opportunity: Options for the future of welfare to work. Leeds: Corporate Document Services.

Furnham, A. (1982a). Explanations for unemployment in Britain. European Journal of Social Psychology, 12, 335-352.

Furnham, A. (1982b). The Protestant work ethic and attitudes towards unemployment. Journal of Occupational Psychology, 55, 255-285. 
Furnham, A. (1983). Attitudes toward the unemployed receiving social security benefits. Human Relations, 36, 135-150. DOI: 10.1177/001872678303600204

Furnham, A. (1985). The determinants of attitudes towards social security recipients. British Journal of Social Psychology, 24, 19-27.

Furnham, A. (2001). Social representations of welfare and economic inequality. In C. Roland-Lévy, E. Kirchler, E. Penz \& C. Gray (Eds), Everyday representations of the economy. Vienna: WUV.

Furnham, A. \& Hesketh, B. (1989). Explanations for unemployment in Great Britain and New Zealand. Journal of Social Psychology, 129, 169-181.

Garver, N. (1965). Varieties of use and mention. Philosophy and Phenomenological Research, 26, 230-238. DOI: 10.2307/2106184

Gibson, S. (2007). Dilemmatic themes in 'lived citizenship': Young people's conceptions of un/employment rights and responsibilities. Manuscript submitted for publication.

Giddens, A. (1998). The third way: The renewal of social democracy. Cambridge: Polity.

Gilbert, G. N. \& Mulkay, M. (1984). Opening Pandora's box: A sociological analysis of scientists' discourse. Cambridge: Cambridge University Press.

Glaser, B. G. \& Strauss, A. (1967). The discovery of grounded theory. New York: Aldine.

Giron, C. (2001). In search of the social representations of unemployment with teenagers. In C. Roland-Lévy, E. Kirchler, E. Penz \& C. Gray (Eds), Everyday representations of the economy. Vienna: WUV. 
Heron, E. \& Dwyer, P. (1999). Doing the right thing: Labour's attempt to forge a new welfare deal between the individual and the state. Social Policy and Administration, 33, 91-104. DOI: 10.1111/1467-9515.00133

Holt, E. (1996). Reporting on talk: The use of direct reported speech in conversation. Research on Language and Social Interaction, 29, 219-245. DOI: 10.1207/s15327973rlsi2903_2

Jefferson, G. (1990). List-construction as a task and resource. In G. Psathas (Ed.) Interaction competence. Lanham, MD.: University Press of America.

Langdridge, D. \& Butt, T. (2004). The fundamental attribution error: A phenomenological critique. British Journal of Social Psychology, 43, 357-369. DOI: $10.1348 / 0144666042037962$

Lawes, R. (1999). Marriage: An analysis of discourse. British Journal of Social Psychology, 38, 1-20. DOI: 10.1348/014466699164004

Le Grand, J. (1997). Knights, knaves or pawns? Human behaviour and social policy. Journal of Social Policy, 26, 149-169.

Lewis, A., Snell, M. \& Furnham, A. (1987). Lay explanations for the causes of unemployment in Britain: Economic, individualistic, societal, or fatalistic? Political Psychology, 8, 427-439.

Lister, R. (2002). Towards a new welfare settlement? In C. Hay (ed.), British politics today. Cambridge: Polity.

Lund, B. (1999). 'Ask not what your community can do for you': Obligations, New Labour and welfare reform. Critical Social Policy, 19, 447-462. 
Lynn, N. \& Lea, S. (2003). 'A phantom menace and the new Apartheid': The social construction of asylum-seekers in the United Kingdom. Discourse and Society, 14, 425-452. DOI: $10.1177 / 0957926503014004002$

Marshall, T. H. (1992). Citizenship and social class. In T. H. Marshall \& T. Bottomore, Citizenship and social class. London: Pluto (original work published 1950).

Payne, M. \& Furnham, A. (1990). Causal attributions for unemployment in Barbados. Journal of Social Psychology, 130, 169-181.

Pomerantz, A. M. (1984). Giving a source or basis: The practice in conversation of telling 'how I know'. Journal of Pragmatics, 8, 607-625. DOI: 10.1016/03782166(84)90002-X

Pomerantz, A. M. (1986). Extreme case formulations: A new way of legitimating claims. Human Studies, 9, 219-229. DOI: 10.1007/BF00148128

Potter, J. (1996). Representing reality: Discourse, rhetoric and social construction. London: Sage.

Potter, J. (1998). Discursive social psychology: From attitudes to evaluative practices. European Review of Social Psychology, 9, 233-266.

Potter, J. (2007a). Discourse and psychology. Volume III: Discursive psychology. London: Sage.

Potter, J. (2007b). Discourse and psychology. (3 vols). London: Sage.

Potter, J. (2007c). Editor's introduction. In J. Potter (Ed.), Discourse and psychology. Volume I: Theory and Method.

Potter, J. \& Litton, I. (1985). Some problems underlying the theory of social representations. British Journal of Social Psychology 24, 81-90. 
Potter, J. \& Wetherell, M. (1987). Discourse and social psychology: Beyond attitudes and behaviour. London: Sage.

Potter, J., Wetherell, M., Gill, R. \& Edwards, D. (1990). Discourse: Noun, verb or social practice? Philosophical Psychology, 3, 205-217.

Rees, A. M. (1995). The other T. H. Marshall. Journal of Social Policy, 24, 341-362.

Reynolds, J. \& Wetherell, M. (2003). The discursive climate of singleness: The consequences for women's negotiation of a single identity. Feminism \& Psychology, 13, 489-510. DOI: 10.1177/09593535030134014

Reynolds, J., Wetherell, M. \& Taylor, S. (2007). Choice and chance: Negotiating agency in narratives of singleness. The Sociological Review, 55, 331-351. DOI: doi:10.1111/j.1467-954X.2007.00708.X

Richardson, J. E. (2001). 'Now is the time to put an end to all this': Argumentative discourse theory and 'letters to the editor'. Discourse and Society, 12, 143-168. DOI: $10.1177 / 0957926501012002002$

Riley, S. C. E. (2002). Constructions of equality and discrimination in professional men's talk. British Journal of Social Psychology, 41, 443-461. DOI: $10.1348 / 014466602760344304$

Rose, N. (1999). Powers of freedom: Reframing political thought. Cambridge: Cambridge University Press.

Schegloff, E. A. (1997). Whose text? Whose context? Discourse and Society, 8, 165187. DOI: $10.1177 / 0957926597008002002$

Seale, C. (1999). The quality of qualitative research. London: Sage.

Sims-Schouten, W., Riley, S. C. E. \& Willig, C. (2007). Critical realism in discourse analysis: A presentation of a systematic method of analysis using women's talk 
of motherhood, childcare and female employment as an example. Theory and Psychology, 17, 101-124. DOI: 10.1177/0959354307073153

Speer, S. A. (2001). Reconsidering the concept of hegemonic masculinity: Discursive psychology, conversation analysis and participants' orientations. Feminism and Psychology, 11, 107-135. DOI: 10.1177/0959353501011001006

Wetherell, M. (1998). Positioning and interpretative repertoires: Conversation analysis and post-structuralism in dialogue. Discourse and Society, 9, 387-412. DOI: $10.1177 / 0957926598009003005$

Wetherell, M. (2003). Racism and the analysis of cultural resources in interviews. In H. van den Berg, M. Wetherell \& H. Houtkoop-Steenstra (eds.), Analyzing race talk: Multidisciplinary approaches to the interview (pp. 11-30). Cambridge: Cambridge University Press.

Wetherell, M. \& Potter, J. (1988). Discourse analysis and the identification of interpretative repertoires. In C. Antaki (Ed.), Analysing everyday explanation: A casebook of methods. London: Sage.

Wetherell, M. \& Potter, J. (1992). Mapping the language of racism: Discourse and the legitimation of exploitation. London: Harvester Wheatsheaf.

Wooffitt, R. (2005). Conversation analysis and discourse analysis. London: Sage. 
Appendix 1: Introduction to the 'Have Your Say' debate headed 'Is the welfare system working?'

(http://newsforums.bbc.co.uk/nol/thread.jspa?threadID=5675\&\&\&\&edition=1\&ttl=200 70730162708; retrieved $25^{\text {th }}$ September, 2007)

Is the welfare system working?

The benefits system should be overhauled to get people back into work, a governmentcommissioned report says.

Welfare payments will be conditional on looking for work and businesses and charities will be offered cash incentives to get people off benefits and back into employment. Under the new reforms, parents could be made to seek work when their child turns 12 , rather than 16 , if they want to receive benefits.

Is the current welfare system working? Should people on benefits be forced back to work? Is it the responsibility of the individual, society or the government to get people back into work? 